Krystyna Szafraniec, Paweł Szymborski

\title{
Transition from Education to Employment: A Specific Character of Rural Youth of the Selected Post-communist Countries ${ }^{*}$
}

\begin{abstract}
The subject of analysis is the process of entering the labour market, considered in relation to the rural youth in selected post-communist countries (Poland, Romania, Russia, China and Vietnam). The empirical basis are different types of existing data (scientific monographs, papers, national and international reports, official statistics) collected in an international project funded by the National Science Centre, Poland. Transition from education to satisfactory employment which, at present times, takes almost the whole third decade of young people's lives, is only an external indication of transformations in the labour markets all over the world. In the analysed group of the countries, Poland is the only case where both using new educational offers and positive valuation of living in the countryside occur to the extent unobserved in other countries; nevertheless, Polish young people also see their life opportunities in the cities where they compete for employment. Rural youth in all the analyzed countries usually represents the type of chaotic careers, situating it in segments of informal work, temporary or self-employment.
\end{abstract}

Key words: labour market, rural youth, post-communist countries.

\section{Introduction}

In the contemporary world, the access to work (employment) has become one of the key factors determining the quality of life, public moods and frameworks

The author is researcher of the Institute of Rural and Agricultural Development of the Polish Academy of Sciences (IRWIR PAN), ul. Nowy Świat 72, 00-330 Warszawa, e-mail: krystyna.szafraniec@umk.pl.

The author is researcher of the Institute of Sociology Nicolaus Copernicus University in Torun, ul. Fosa Staromiejska 1a, 87-100 Toruń e-mail: pawelszymborski89@gmail.com.

* The article was written within the framework of the project financed with NCN funds: Młodziez $w$ krajach post-komunistycznych. Potencjat innowacyjny, nowe konteksty, nowe problemy i nowe wyzwania, No UMO-2013/08/M/HS6/00430. 
of social tension. Simultaneously, work - as the result of different circumstances (civilisation, related to economic recession, global trends) - has become a good in short supply. The young generation is hit the hardest by work deficit, and the fact that it has been growing up surrounded by the culture of consumption, which promotes individual success and well-being, is of great significance here and bears specific social consequences. Also, as ILO (International Labour Organization) reports show, unemployment, economic activity and employment rates have been much promising for adults than for youth for many years. Due to legal regulations and employers' preferences, even those young employees, who have found their place in the labour market, cannot count on stable employment. They are offered unstable and pluralistic forms of temporary underemployment. There are several reasons for this situation. The first and basic one is a liquid nature of postmodern capitalism, another one is education maladjustment to changing and amorphous requirements of the labour market. All of these result in a contemporary increase in uncertainty concerning satisfactory transition to the labour market and the need to face risks related with unstable economy. To different extents, today these challenges concern developed as well as developing countries, but it is the latter ones which have considerable difficulties with facing them.

The subject of our interest are post-communist countries which, in many respects, meet/have the definition criteria/features of developing countries. One of these features is rurality, which could be described in demographical, economic and social categories as a systemic specificity, problem and challenge. The question we are posing here concerns the life strategies of young people living in rural areas of the selected post-communist countries. We are especially interested in the transition from education to employment which is of key significance in achieving life independence, as the achievement thereof determines the social standing and successful life of people despite being very difficult and burdened with the risk of failure. How do rural youth goes along this path and what is its place in the social structure determined by the transformative reality of the post-communist countries?

This article is based on data gathered within the international project implemented thanks to a grant from the National Science Centre. The participants include nine countries; apart from Poland these are Bulgaria, Latvia, Russia, Romania, Hungary, Vietnam and, comparatively, Germany (eastern lands). On the basis of the existing sources (monographs, national and international reports, and official statistics from individual countries ${ }^{1}$ ) we focus on a multifaceted

1 In international reports, selection of units for analysis and the methodology set out the principles accepted by international organizations. They are imposed on local institutions which collect relevant 
description of the situation of the young generation and ask in what direction the system transformation should go if these will be determined by - on one hand innovation resources of the young generation (its competences, aspirations and life orientations) and on the other hand - structural possibilities and limitations generated by the system. Questions concerning rural specificity were not the main ones the project focused on - they were only among many others. For the purposes of this article, we have chosen the issue which shows rurality as a still existing problem in post-communist countries. Due to restrictions of the length of the article and some methodological problems (incompleteness of data from local, national sources, the lack of comparable - international - data for all the countries analysed) we limited our study to those countries which represent some special cases, and at the same time show the post-communist space as internally diverse. These are - apart from Poland - Romania, Russia, Vietnam and China. The first two represent Europe, the last two Asia and the features of Russia, as an Eurasian country, place it between these "polar opposites". In each of these countries, the rural population constitutes a demographic potential of considerable percentage, and rural areas and agriculture are transformed according to different patterns. This is visible in structural changes, reforms and funds directed to these sectors and, finally, in the role public policies and social perception assign to them.

\section{Rural and agrarian areas of the analysed countries}

In most of the developed countries, rural areas and agriculture have long undergone fundamental metamorphosis. Post-communist countries are highly diverse in this regard. Poland, after its accession to the European Union, was the biggest enclave of peasant farming which was almost extinct in the Western European rural areas, and a specific series of economic, social and political events made Polish agriculture undergo a complete transformation although there are still many problems to solve (Wilkin 2010, p. 177; Wilkin, Nurzyńska 2016). Rural areas and farmers have become the major beneficiaries of European Union's support which has significantly changed the condition and image of Polish rural areas (Knieć 2012, pp. 132-151). Romania is one of the countries where agriculture still plays a considerable part in the economy, which also uses EU funds but these are (a) much smaller, (b) differently distributed. ${ }^{2}$ Their main recipients are large farms. Smaller farms and rural areas in a wider social

\footnotetext{
data, thus gaining comparative value. If we refer to the results of sociological research we do it in order to complement the characteristics of countries under analysis and to better understand their specifics.

2 The subsidies for farmers for 2008-2013 in case of Romania amounted to EUR 6,896 million; in Poland EUR 14,808 million - cf.: http://farmsubsidy.openspending.org (own calculations). From 1 May 2004 to 30 November 2015 r. the accounts of the Polish National Bank were credited with EUR 122.45 billion
} 
sense use the EU funds to a much lesser extent, which preserves their traditional character. Russian agriculture struggles with considerable problems. As a result of reforms introducing free-market principles to the agro-industrial complex, the number of agricultural enterprises (sovkhozes and kolkhozes) has been reduced by $56 \%$ (and a half of them are currently unprofitable) and the rural areas have become a place of extremely unpromising life prospects and a great number of social problems (Mukhanova 2014). In China and Vietnam, rural areas and agriculture are subject to moderate market transformations. Land tenure has been prolonged and the allowed arable land area has been expanded (up to $1 \mathrm{ha}$ ); specialized production is promoted. However, this does not basically change an image of the rural areas of that country as backward and poor, deprived of external and internal resources. As a consequence of very strong dynamics of economic changes in China rural areas which have been rapidly depopulated undergo a process of marginalisation. The reason behind this is a dynamic modernisation of cities demanding cheap labour, as well as a lack of systemic solution to the problem of agriculture and ownership in agriculture. Vietnam, following the footsteps of the Chinese reforms, experiences similar problems, however, of a wider scope. Backwardness and poverty in the rural areas are even more considerable while the country's development dynamics, although quite noticeable, has got more challenges to face. Due to these circumstances, among others, the social mobility of rural residents is very limited in Vietnam. Even economic migrations to financially resilient zones involve "riding at anchor" and attachment to a family village which preserves its traditional image and structure (Nguyen An Ha 2014). Nevertheless, even such traditional agriculture has got a considerable contribution to Gross Domestic Product (GDP) growth (17.4\%). In China, it is half that size and in other countries it is inconsiderable (Figure 1).

In Vietnam, almost half of the workforce works in agriculture. In China, 1/3 of the workforce generate their income from agriculture. Romanian agriculture gives jobs to almost $28 \%$ of those employed, in Poland it is $12.6 \%$. Russia is the least "agricultural" - the agricultural sector employs only one-tenth of the general employed population (Figure 2).

Regardless of differences, rural areas are still a place of living for a large part of post-communist countries' population. In this sense, Russia is the least rural only $26 \%$ of its citizens live in rural areas. In Poland and Romania it is, respectively, $39.4 \%$ and $46.1 \%$. In China, almost half of the population (49.7\%) lives in the country, in Vietnam it is two thirds (66.9\%) (United Nations 2014). Almost in every analysed country, the percentage of children and youth living in the countryside is a bit higher than in the city but the percentage of young adults is lower, which

from the EU. During that period, Poland paid the EU EUR 38.7 billion which gives a net balance of EUR 83.57 billion - cf.: Nurzyńska 2016. 
is basically the result of their outmigration to cities. Poland is an exception here the countryside as a place for living is increasingly becoming popular. In Vietnam family bonds and dependence on family support keep a big number of young people in the countryside. In Russia, between 2002 and 2010, the population of rural areas decreased by 1.2 million people - mostly young people escape from there (facing unemployment, no paid job or life prospects) (Mukhanova 2014, p. 127). A similar trend is observed in Romania although rural areas there are becoming a shelter for those who have not succeeded in a city (Tudor 2014; Catrina 2015). In China, in search for a better paid job, only in 2011, 14.6 million people moved to a city. ${ }^{3}$ They form a very specific category of the so-called new migrant workers worse-class citizens with neither the right of registered residence, nor social security, getting offers of badly paid jobs mainly in the informal employment sector (Chan, Ngai 2009; China Youth Employment Report, 2005). They take these jobs as living conditions and prospects are far more hopeless. Vietnam still represents the society of people "equal in poverty"; however, there are some differences between rural and urban areas and, especially, differences in life prospects.

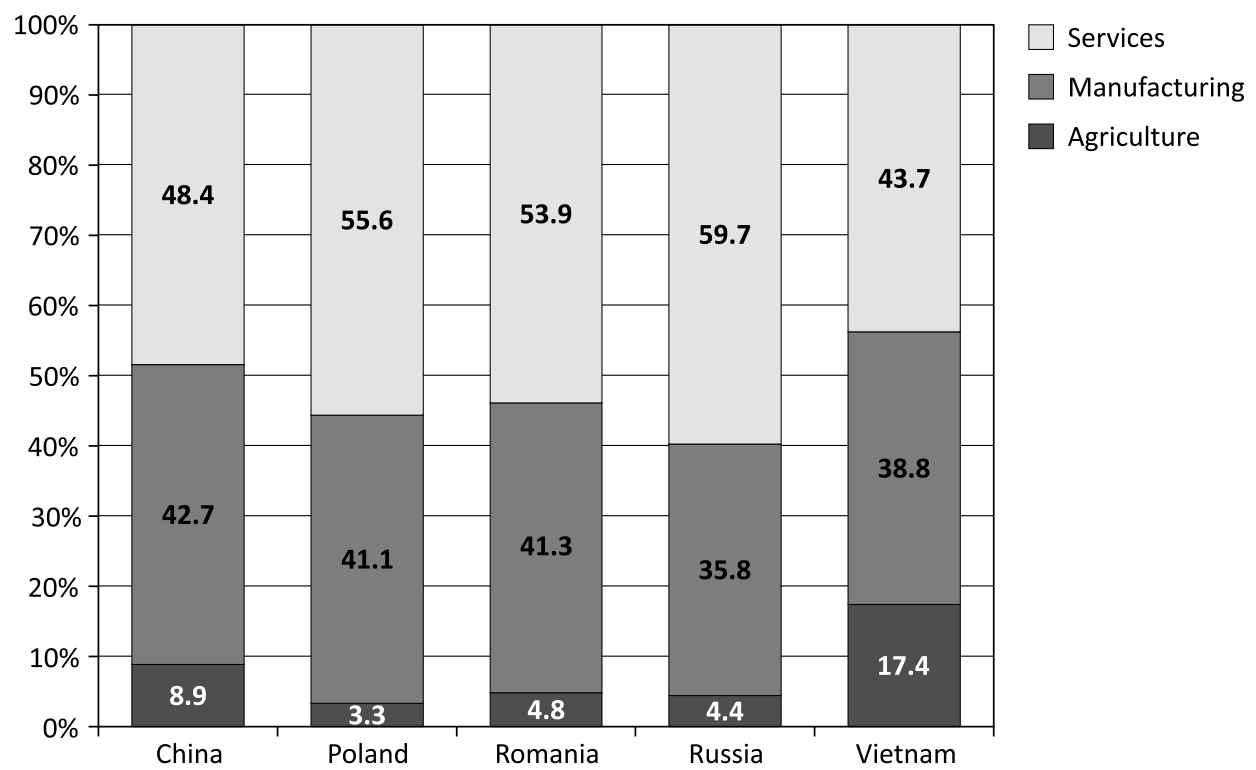

Figure 1. Gross Domestic Product (GDP) - composition, by economic sectors (2015) Source: CIA database.

3 Data of Central Statistical Office in China - cf.: WanChun Luo, Socio-cultural background and transformation processes in China, materials (pptx presentation) prepared for the purposes of the seminar organised within the frameworks of NCN project, May 2015, Sopot. 


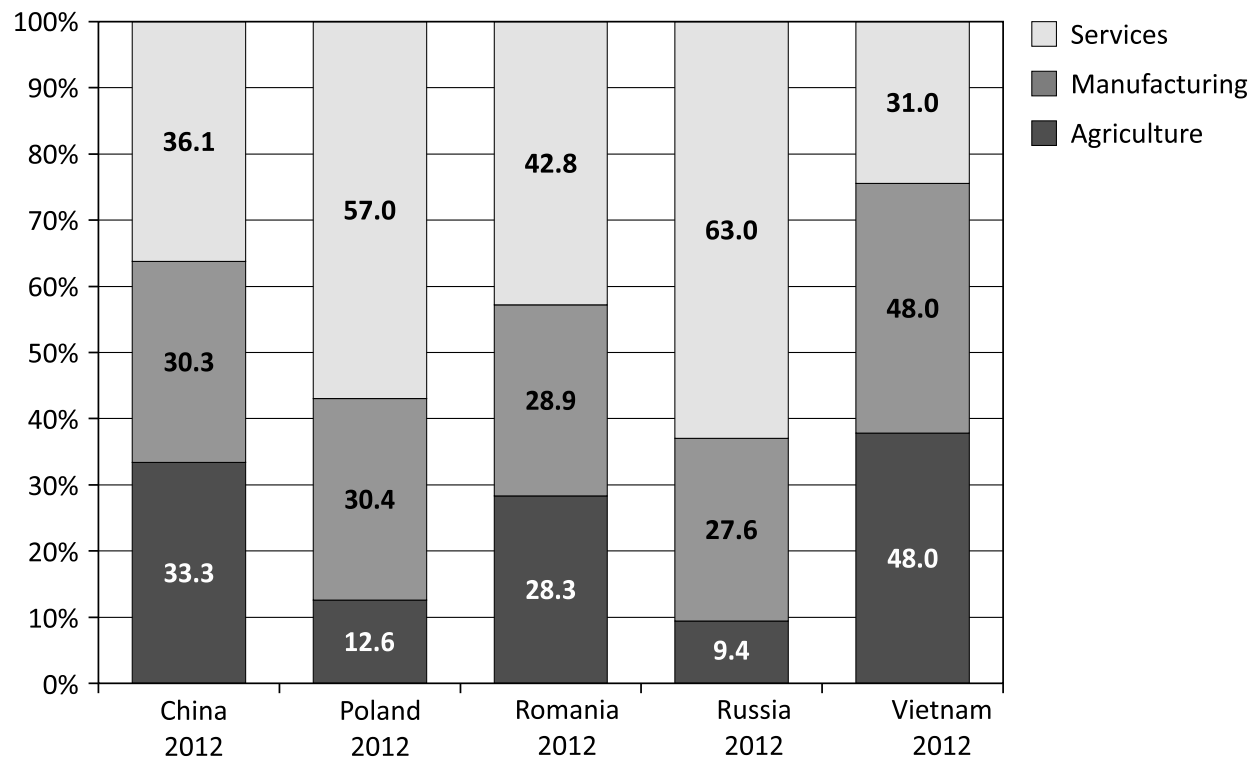

Figure 2. Labour force - by sector of economy

Source: CIA database.

In every post-communist country, the above-mentioned differences are considerable and rural areas (and especially agriculture) are not perceived as an offer for the future in most of the cases. They become a place for those who left the education system prematurely and graduated from low-ranked schools (negative motivation) or, in contrast, for those who notice positive qualities in the countryside, such as natural and health benefits or an opportunity to fulfil professional aspirations (positive motivation). Among the analysed countries, only Poland has been successful in overcoming stereotypes of the countryside as a civilisation backward place associated only with agriculture and deprived of any other qualities. However, generally, rural youth plan their future outside of the rural areas regardless of their country. They are aware of many risks together with those connected with the labour market as the most considerable ones. Today, they equally concern the developed and developing post-communist countries where not only unemployment but also temporary employment have become natural elements of the social landscape, and the fear of unemployment makes job insecurity complete and this cannot be overcome by the new system. 


\section{From education to employment - preparations and barriers}

Education has become a core value and a pillar of youth life strategies reflected not only in their higher educational aspirations but also in higher actual education level indices. This universal trend had different ranges in different countries and, depending on the point of departure (and local flavours), gave different social effects. Poland is an example of the country where the educational explosion post 1989 (a fourfold increase in a number of students) was off the charts in Europe. The costs of education and educational success were mostly borne by families. Investment in education was a major expense of the household budgets - both in rural and urban areas - and the wide offer of non-public universities established by virtue of the new law turned out to be (with regard to undemanding enrolment procedures) a chance for young people of worse-off families especially from rural areas. They have been the main clientele of non-public universities - despite limited financial resources and other families' expenses. What is important, $30 \%$ of youth of rural origin who graduate from universities, return to the countryside. Apart from them, there are young people with no rural roots coming to rural areas (Wasielewski 2013). As a result of these processes, the educational structure of young residents of Polish countryside (aged 25-29) presents itself in a much better light than in the $1990 \mathrm{~s}-26.2 \%$ of them hold a university degree, $36.7 \%$ are high school and postsecondary school graduates, $34.1 \%$ are basic vocational school graduates, and 7.4\% finished their education at primary level (Nowak et al. 2013).

One may use the notion of educational explosion also in the case of China although there, the educational drive is hindered by poverty of a huge number of people living in the rural areas, the situation of worse-off urban families, especially new migrants deprived of many rights and possibilities, including sending their children to public schools that parents simply cannot afford. ${ }^{4}$ Despite these facts, family investment in education in China is increasing - by an average annual rate of $29.3 \%$. Chinese families are now spending $10 \%$ of their total household expenses on investment in education, compared to the $7.1 \%$ they spend on housing. Moreover, people tend to be more ready to invest in education than in housing. Education consumption has become a new hot spot for Chinese household investment (Xi, Xia 2006, p. 82). Today, there are over 54 million young people studying in China which, compared to young population aged 15-35 of 471.271 million people, is not necessarily a stunning number but when compared to the period of the Cultural Evolution and its effects, it is a great change showing the increasing value

4 Public school admission requires parents' permanent registered residence, employment and proper earnings which would guarantee that they can afford a school starter kit, etc. In the case of new migrants these conditions are most often difficult to meet (Chinese citizens living places of permanent residence become second-class citizens starting new lives far away from their families at their own risk). 
of education in that country. This does not change the fact that the educational structure of young Chinese people aged 16-29 still diverges from the European standards. $12 \%$ receive primary education, $63 \%$ - middle school education, $17 \%$ are secondary school graduates and $7 \%$ are university graduates (1\% are illiterates) (China Youth Employment Report 2005, pp. 3-4). Despite reforms within the scope of educational policies there are still serious inequalities between rural and urban areas, ethnic groups and regions (Tang 2016, pp. 2-3). In one of the major Chinese universities (Beijing Normal University), new students from rural areas constituted $27.3 \%$ of the whole university population in 1985 ; in 1999 this was only $16.3 \%$. The rest of the students are admitted to low-ranked schools which hinders the obtainment of high-quality education and results in fewer good job opportunities (UN HABITAT \& IESCO 2015, p. 8).

In Russia, after a period of illusions that one may be professionally successful without a university degree (the 1990s), there was a rapid increase in educational aspirations of the youth who, after 2000, have been increasingly better in sensing labour market trends and drawing conclusions. Up till 2010, a number of students in Russia increased 2.7 times. However, the rural youth participation in these changes is not as broad as in the case of urban youth and rural areas are not taking advantages from these changes. Between 1994 and 2011, the percentage of young people (aged 15-30) with completed secondary education decreased from over $50 \%$ to below $40 \%$. At the same time, the percentage of youth deciding to finish their education before completing secondary education level and starting different forms of vocational training rapidly increased (from $23 \%$ to $37.2 \%$ in the group of 15-22 years of age). Furthermore, the percentage of rural youth going to universities also increased - from 11\% in 1994 to $19 \%$ in 2011, which, with declared willingness of going to university of $64 \%$ in the case of 15 -year-old youngsters and $78 \%$ among 20-24-year-old people, does not seem to be a special achievement - despite many non-public higher education offers available (Mukhanova 2014, pp. 131-136). What's important, the rule is that those who go to universities settle in cities which give social advancement opportunities. According to Russian research, only $3 \%$ of graduates return to the countryside (Mukhanova 2014, p. 132).

A different situation is found in Romania and Vietnam where education per $s e$ is at stake and where youth not only do not pursue higher education so eagerly but also much more often discontinue education below this level for different reasons (ethnic, cultural, high costs of education, and poor absorptivity of labour markets). In Romania, early school leavers index is 19.1\% (EUROSTAT database: edat_lfse_14 dataset, 2015); in the case of rural youth it is $27.7 \% .{ }^{5}$ High school

\footnotetext{
5 In contrast, in Poland, 3.8\% of youth drop out of school; in rural areas it is $6.1 \%$ (downward trend).
} 
graduation index is much lower in rural areas (71.4\%) than in urban areas (94.7\%). The reason for this is not only a bad economic condition and low cultural capital of rural families as well as a bad condition of rural education system, but also mostly urban (i.e. expensive) location of high schools. As a result, rural youth most often choose vocational schools which are very low ranked in Romania (these are mostly for educational nonstarters) and they constitute $2 / 3$ of these schools population. The interest in graduating from high school and university visibly dropped over past years by approximately $10 \%$. In 2012, the youth of rural origin constituted only $24 \%$ of the whole group of students (Balica 2014). As much as $62 \%$ of rural residents (aged 15-24), 42\% of a bit older ones (25-34) and 32\% aged 35-49 completed only primary education level (Tudor 2014).

A challenge for Vietnam is being created by a situation where rural youth would successfully complete a primary education and start a vocational training. So far, more than a half of Vietnamese students drop out of school and this is mostly rural youth (Survey Assessment of Vietnamese Youth 2). The reasons are the same as in Romania - poverty in the countryside, long-term negligence in the education system, its underfunding, power of tradition enabling everyone to survive in the countryside but also a lack of strong enough stimuli of the economy and labour market which need qualified (experienced) workers more than specialists with a diploma. According to ILO data, in 2013, 10.8\% of rural 15-29 year-old people in Vietnam did not even complete a primary education level, $24.5 \%$ completed primary education, $60.4 \%$ graduated from post primary schools (mainly junior high schools) and $4.3 \%$ graduated from a higher education institution (in comparison to $20.5 \%$ in the city) (Elder et al. 2015, p. 14).

At the same time, a large part of the youth from the post-communist countries who decided to go to universities experience disappointment. A diploma, which was supposed to guarantee not only job security but also advancement, so important to rural youth, more and more often fails to do so. The phenomenon of overeducation (excessive formal qualifications in relation to the requirements of a job position and even workplaces) and opposite thereof, underemployment, are observed in every post-communist country. The research conducted in six European countries showed that the phenomenon of overeducation is more popular among university graduates than unemployment and it is $17.3 \%$ in Slovakia, $17.9 \%$ in Hungary, $18.4 \%$ in Poland, $20.8 \%$ in Bulgaria and over 25\% in Slovenia and Estonia (Ilieva-Trichkova, Boyadjieva 2014). ${ }^{6}$ In Vietnam, the phenomenon of overeducation concerns $30 \%$ of

6 Maladjustment of education and employment among people who obtained higher education is strongly related to institutional qualities of higher education institutions - their structure, quality of education, symbolism - see: Boyadjieva, Ilieva-Trichkova 2015. 
the graduates and results mainly from maladjustment of old structure of education to the requirements of a new labour market (Survey Assessment of Vietnamese Youth 2).

The limited possibilities of employing people with high qualifications are determined by a difficult economic situation resulting from a worse condition of post-socialist economies and effects of the global crisis as well as incompatibility of the education offer with the labour market's needs and social trust in the power of a diploma (credentialism). This is most of all demonstrated by youth originating from families where there are no traditions of investing in higher education and schools are chosen within easy reach, disregarding their low standards of studies and low requirements for obtaining a diploma which, although easily obtainable is worthless in the job market. The network of non-public tertiary education institutions, which has developed in all post-communist countries, has become paradoxically - an offer which is used mostly by worse-off, including rural, families. Everywhere - in all the countries - a low quality of such schools is commonly complained about. What is more, the criticism of public (state) higher education institutions is increasing as they are having difficulties with shifting into the type of education which takes account of new market context and with defining their own role. Similar problems are encountered by vocational education and training systems. The counselling system is hardly effective (educational, vocational coaching), although so important in the face of the changing and hardly predictable labour market, especially to the youth who, not knowing themselves, or social needs or future trends, often make ill-considered choices. This does not affect so much the youth from urban, especially wealthy, families where well-thought educational strategies are planned and implemented very early, and the comparison of post-communist countries (regardless of whether they are in Europe or Asia) with the developed countries of Western Europe (in our project Germany was the point of reference) shows that investment in education of children is more compulsive in post-communist countries than in the West.

\section{Entering the labour market and employment}

Transition from education to employment is defined as a period within which young people should "theoretically" end their formal education, find a job consistent with their qualifications and reach financial independence. ${ }^{7}$ In reality, there are

\footnotetext{
7 Stages of transition are defined as follows: "A young person who has 'transited' (completed their labour market transition) is defined as one who currently has (i) a stable and satisfactory job, (ii) a stable but non-satisfactory job, (iii) a satisfactory but temporary job, or (iv) is self-employed and satisfied with their job. A young person is considered 'in transition' if he or she (i) is currently unemployed (relaxed
} 
many career paths to follow. Studies are combined with part-time jobs, and formal education is replaced and completed with a number of extra training courses, internships and tutelage. Today these new patterns which make the transition a sequential process, are popular in every country, also post-communist ones (continuing education, undertaking family obligations, postponing). However, there are considerable differences between European and Asian (post)communist countries.

While in Europe the process of transition from education to employment has been delayed, complicated and prolonged, in the case of youth from Asian countries (China and Vietnam) it starts earlier, is less complicated and shorter. Different patterns of entering into the labour market - due to a long period of education (usually related with obtaining professional experience) and short period of education (failing to provide students with suitable qualifications) - are related with different types of problems. The former generates the effect of overeducation and the phenomenon of underemployment. The latter is related to the opposite phenomenon - insufficient level of education (undereducation) compared to the needs of the labour market, which results in constant balancing between temporary forms of employment (in informal or gray economy) and a lack of employment. This problem occurs in every (post)communist country and rural youth take this path increasingly often.

According to SWTS (School-to-Work Transition Survey) ${ }^{8}$ research, it is clearly visible in Russia (urban youth are much more often employed in stable or satisfactory temporary jobs than rural youth, who are more often professionally passive or continue education in cities) (Table 1). Vietnam is in a more balanced situation a similar percentage of rural and urban youth aged 15-29 found a steady job (in the case of rural youth, it is mostly employment in the agriculture) - and the rural youth, more often than in the past, remain at the stage of searching and experimenting and that means that they do not see themselves in the agriculture as often as before.

definition) or (ii) has currently a temporary or non-satisfactory job or (iii) is currently self-employed and unsatisfied, or (iv) currently has no job and is not at school, but has an intention to look for work later. A young person who has 'not yet transited' is one who is either still in school (non-working students) or currently is not working and is not attending school (and has no intention to look for work)" (Elder et al. 2015, p. 28).

8 The research included most of all the developing countries, and in the case of the ones interesting to us, there were only Russia and Vietnam - see: Elder et al. 2015. 
Table 1. Youth population (aged 15-29) by stages of transition and area of residence in 2012-13 (\% of total employment)

\begin{tabular}{lcccccccc}
\hline Country & \multicolumn{2}{c}{ Transited } & \multicolumn{2}{c}{ In transition } & \multicolumn{2}{c}{$\begin{array}{c}\text { Transition } \\
\text { not yet started }\end{array}$} \\
& \multicolumn{1}{c}{ Urban } & Rural & Urban & Rural & Urban & Rural & Urban & Rural \\
\hline Russia & 53.1 & 42.2 & 12.2 & 18.6 & 30.8 & 26.5 & 3.8 & 12.7 \\
Vietnam & 55.0 & 55.3 & 12.4 & 21.1 & 32.3 & 23.1 & 0.4 & 0.5 \\
\hline
\end{tabular}

Source: Elder et al. 2015, pp. 57-58.

This sector, which at the end of the 20th century was still an absorber of excessive labour force and an alternative for (overt) unemployment, is not such an alternative to rural youth today. In Poland, the agricultural sector engages less than $8 \%$ of young labour force, in Romania, it is over $22 \% .^{9}$ In the case of Asian countries - China and Vietnam - the percentage of young people in agriculture is much higher and it exceeds 30\% (International Labour Office 2015, p. 29; China Youth Employment Report 2005, p. 32). In Russia, it is 15\% (International Labour Office 2015) and that means a considerable decline in the past 12 years - a mean annual young people's migration from agriculture is estimated to be 400 thousand and this much exceeds mean numbers for the general population leaving this sector (Mukhanova 2014, p. 129).

Young Vietnamese people enter the labour market the soonest - as much as $64 \%$ of rural youth drop out of school after junior high school and start their struggles with the labour market (Figure 3).

In all the analysed countries, the percentages of people active in the labour market are higher in the case of rural youth (from several to several dozen percentage points). This may have three causes: first, a lack of optimal conditions to continue education; second - a great demand for unskilled workforce; third financial pressure (own or of a family). These causes are not necessarily exclusive in some cases they may co-occur and cumulate showing the range of difficulties related to finding a proper job.

9 Own calculations on the basis of EUROSTAT. It is worth to mention that despite results' variance between European countries (for instance, the mentioned high percentage of young people working in the Romanian agriculture), the mean value for the European Union is 3.4\%. This shows a tremendous difference in the employment structure between the countries of Western Europe and post-communist ones. This is another example of a great dissonance between the significance of agriculture to Romanian economy and the high percentage of young people working in agriculture. This observation itself shows that the working conditions in Romanian rural areas may differ from young people's perception of proper working conditions. 


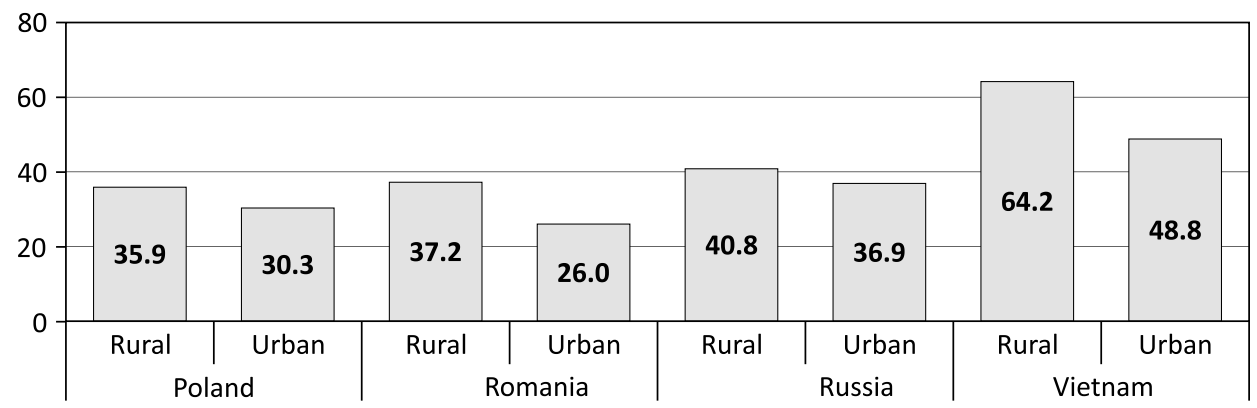

Figure 3. Labour force participation rate by age (15-24) and area of residence in \% (2015)

Source: ILOSTAT database.

In the countries with traditional agriculture and a simultaneous inconsiderable absorbing power of urban labour markets, official youth unemployment rates are lower than in the case of cities. This results from a protective function of a farm which becomes a waiting room for young workforce and enables them to survive. This is the case, for instance, in Romania and Vietnam (Figure 4). In the countries where villages' character is not mainly agricultural and working in agriculture does not seem to be an alternative (as they are non-agricultural job markets), unemployment rates are higher among youth (examples here are Poland, Russia and China).

The last straw in addition to the problem of unemployment, together with shrinking workforce resources, is a growing number of people who are in working age but do not work and are not deemed unemployed at the same time (in Polish passive working age people). Passivity - in contrast to unemployment - may result not only from objective but also subjective reasons. A special category is formed by people included in NEET ${ }^{10}$ - who are not in education, employment or training. NEET index reveals the percentage of youth who are threatened with a permanent loss of touch with the labour market. Our analyses show that high and relatively stable percentage of NEET category is specific for all the post-communist countries (Figure 5), and the detailed (local) analyses show their higher values in relation to rural areas. It seems that the young people in China are in an especially difficult situation, where despite high employment percentage, the NEET category has rapidly increased in the past years.

10 Acronym for not in education, employment, or training. 


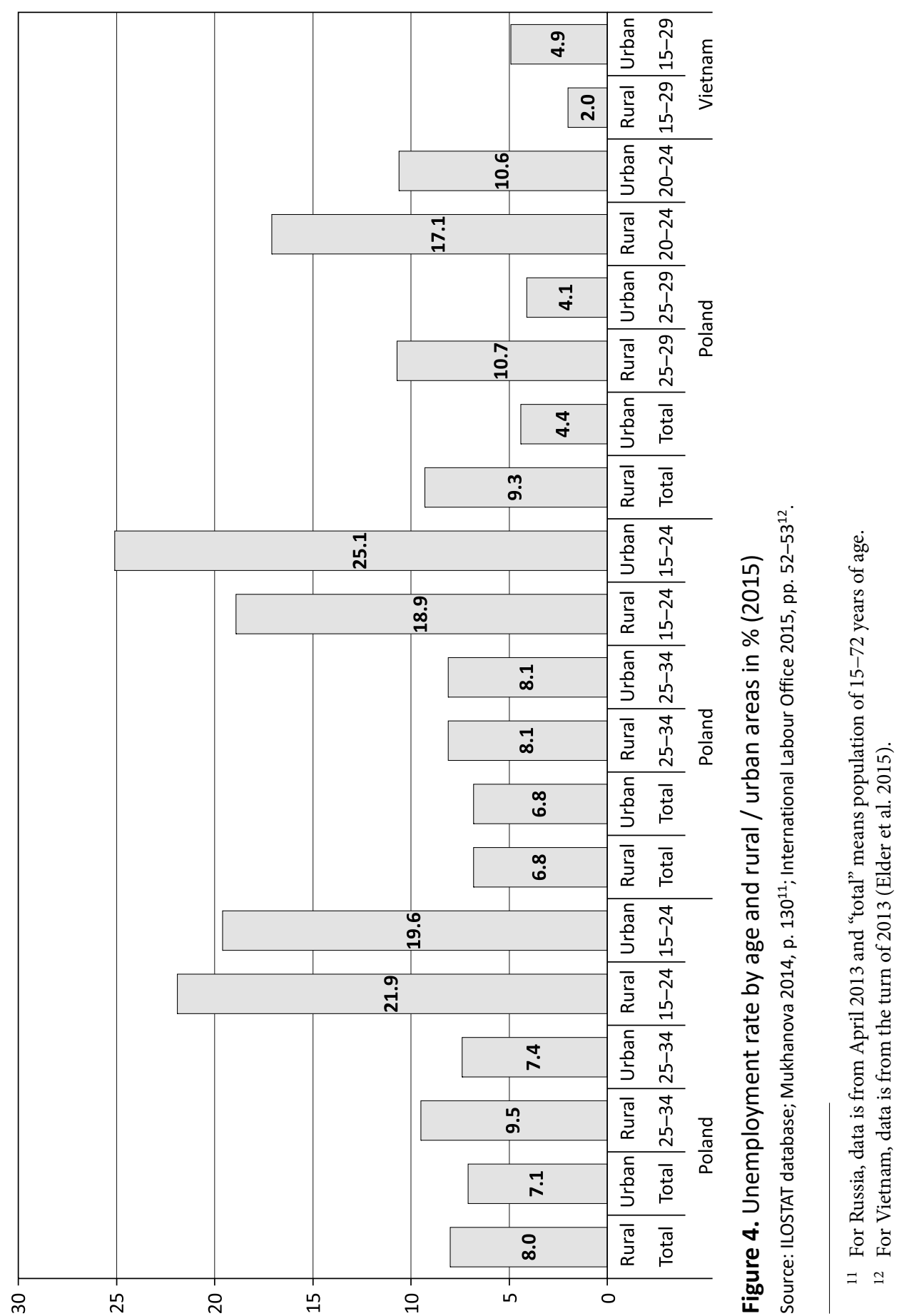




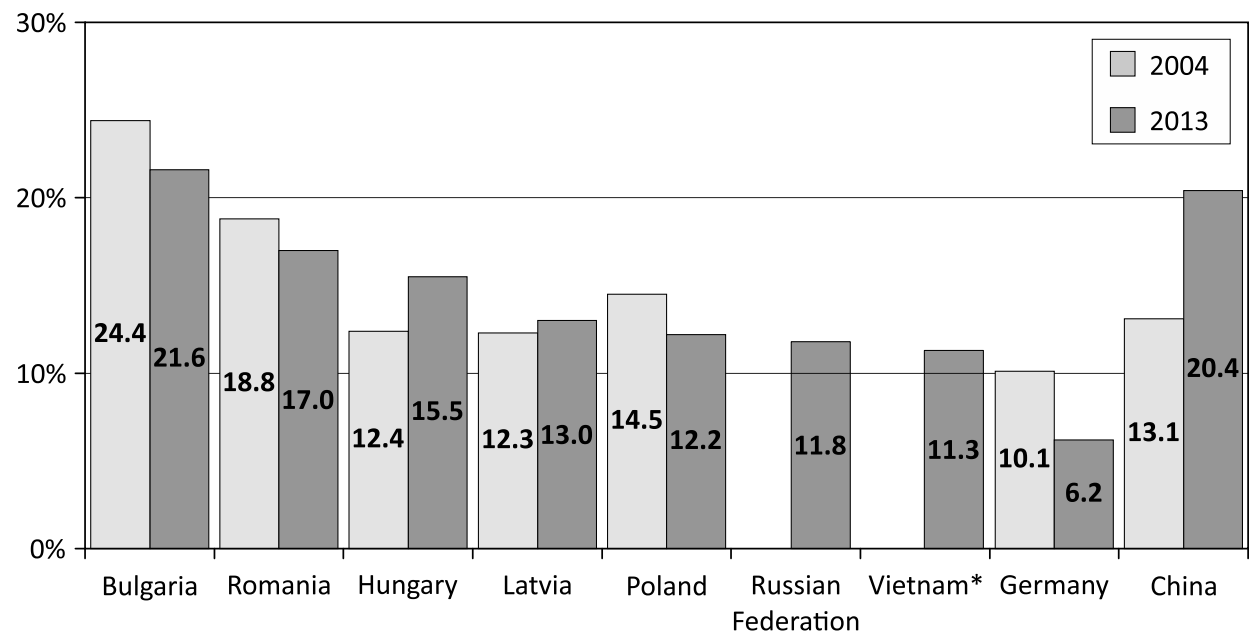

* For Vietnam data is for 2012. Data for Russia and Vietnam for 2004 is not available

Figure 5. The percentage of youth aged 15-24 in NEET category

Source: own work on the basis of: ILOSTAT database; Chunling Li 2015, p. 139.

Deteriorated conditions on rural labour market push young people towards non-standard employment forms. The area they enter the most often is the grey economy sector - which is especially vast in Russia, China and Vietnam - 25-55\% of youth aged 15-29 work there. In 2011, in Russian informal employment sector, there were $40 \%$ of young people aged 15-24 and 30\% aged 25-29 (older cohorts $-24 \%$ ). To $33 \%$ of young people this sector was the main place of employment (and, most probably, the main source of income). In the rural areas, $87 \%$ of the young people work in the grey economy sector; these are mostly people with incomplete secondary education (Mukhanova 2014, pp. 144-145).

\section{Migration to cities as a way of finding a job: China example}

Migration to cities is another frequently used method of finding a job. A lack of life opportunities related to living in the rural areas of the developing countries causes a high level of migration to cities. The migrants end up mostly in the poor urban districts - slums - and increase the range of poverty of urban citizens (United Nations 2006). China is a good example of a series of social and structural factors resulting in increased migration of rural population to cities. People moving to the countryside constituted the majority in over 30 million migrants of the period of 1985-1990 (Zhang 2004, p. 15). A fear of uncontrolled migration of too many people from rural areas triggered the implementation of Hukou registration system 
already in the 1950s. However, in transforming China, this system brings about numerous problems: it limits mobility, Chinese economy needs, and possibilities of social advancement. People from a particular registration area have bigger chances to find a job there than the ones from outside of that area. Especially rural youth who went to big cities to obtain education, encounter difficulties - only a small part of them find a job and even smaller percentage find acceptance of local governments and receive social rights (UN HABITAT \& IESCO 2015, pp. 42-43)..$^{13}$ The policy of Hukou system is gradually toning down in provinces but this does not change the fact that legal changes are not necessarily followed by mindset of officials and employers who have been strictly complying with the binding rules for decades (Xi, Xia 2006, pp. 93-94).

Migrations, while solving one type of problems, cause other ones. There is a growing number of single-person households dodging the official system in Chinese cities. Only in Shanghai itself, in 2010, these households constituted 17.2\% of the total number of households (nation-wide, it was 13.7\%). More than a half of them $(60 \%)$ was established by rural migrants. Among young single-person households (run by people aged 15-24), almost $90 \%$ were rural migrants $(\mathrm{Hu}$, Peng 2015, p. 14). Because of increased migrations, the percentage of the so-called "generation-skipping households" has increased. In 2010, it was $2.26 \%$ of the total number of households (that meant an over threefold increase since 1982). Over a half of these households (51.2\%) was located within rural areas. ${ }^{14}$ In 2003, within the total number or rural workers having a job outside a family village, $47.3 \%$ were young people below 25 years of age (Xi, Xia 2006, p. 87). For the ones who have invested considerably less in education a job in a city most often means a hard physical labour, which is badly-paid and risky (construction and production workers, etc.) (Xi, Xia 2006, p. 100). System and social constraints (aversion of the system and people to newcomers) together with lower-quality preparation for functioning in the labour market make young people who pinned their hopes on migration to cities often fall into another cycle of poverty, while simultaneously losing contact with the community which would provide better support (but not better conditions or more attractive lifestyle). This is considerably different between young rural migrants and their peers from the cities (Umbreş, Sandu, Stoica 2014, p. 8), and

13 At the beginning of 2014, a court issued an unprecedented judgement which found for a person who accused local self-government of a lack of possibility of applying for a legal job outside of Hukou registration region (Elder et al. 2015).

14 "Generation-skipping household" category refers to households composed of grandparents and grandchildren with no generation of parents (who migrate in search for a job). It is problematic as it does not mention the time of parents' absence at home and their economic activity as well as protectiveness towards other generations (grandparents and children) (Hu, Peng 2015, pp. 14-15). 
the pressure of consumption - many times higher than in the previous living environment - intensifies the frustration which is visible in political orientation or a level of social participation.

\section{Conclusions}

Transition from education to satisfactory employment which, at present times, takes almost the whole third decade of young people's lives, is only an external indication of transformations in the labour markets all over the world. In the case of post-communist countries, the burden and risks resulting from this process (unemployment and its peculiar, postmodern form, i.e. changing, pluralistic forms of part-time, temporary employment) are borne not so much by the institutions as by people. While discussing the analyses that we have conducted in the international project including nine post-communist countries, this article pondered on the issues of rural youth and their ways to find themselves in these changes - what patterns of transition (from education to employment) and what places in the social structure are determined for them by transformation reality of these countries.

In the developed European countries, changes in the labour markets result in different (more pragmatic) attitudes towards education, make educational strategies more sophisticated and extend the period of education. Although in the post-communist countries, one can observe the same reaction, those changes are more inflexible and compulsive in nature, which is especially visible in the environments where investing in education has never been one of the cultural rituals. The difference is clearly visible in a strong belief of the representatives of lower social classes (including rural youth) in the power of a university diploma (regardless of its quality), which is reflected in a phenomenon which is very specific for post-communist countries, and which involves going to easily accessible tertiary education establishments which do not set high requirements... Non-public higher education institutions which have been established in every post-communist country are an example of such establishments. Graduating from these institutions gives a chance for advancement, but it poses a risk of losing the employment competition, which for the graduates concerned means a long time of seeking a good job, which does not create a pattern of a satisfactory career.

However, most of the rural youth do not go to universities; they end their education at a very low level or even drop out of school (which is specific for Asian countries such as China and Vietnam, as well as Romania) or choose vocational training instead (as in Russia or Poland). Entering the labour market through these career paths is becoming increasingly difficult. In rapidly developing China, which focuses on a hasty modernisation of cities, poorly educated rural youth 
constitutes the main flow of migrants living in "invisible" (not included in the official registers) suburbs where they may find short-term, badly-paid jobs in the grey economy sector.

In all the post-communist countries, rural areas as a place of living are at a disadvantage in comparison with the possibilities young people find in the cities, and these processes are intensified by the influence of the culture of consumption reaching rural youth via the modern media on one hand, and the effects of system transformation which cannot handle modernisation of the agricultural and rural sector on the other hand. The selected cases have certain similarities, but there are also differences related with a specific character of system changes in the particular country, financing of the agriculture and rural areas or the level of city's competitiveness. In China, Russia and Romania, the willingness to escape from the village is very strong, but only the youth of the first two countries are successful in migration (despite the costs they borne). In Romania, a trend consisting in young people's returning to the countryside is intensifying (as the result of negative experiences connected with the labour related migration). In Vietnam, migration movement between rural and urban areas does not considerably reduce human resources in the countryside. Strong bonds in local communities and traditional character of a family give a feeling of support and security which are much more significant to a large part of rural youth than uncertainty of living in the city and separation from the beloved ones. In the analysed group of the countries, Poland is the only case where both using new educational offers and positive valuation of living in the countryside occur to the extent unobserved in other countries; nevertheless, Polish young people also see their life opportunities in the cities where they compete for employment.

\section{Bibliography}

Balica M. (2014). Rural-urban disparities in education - Romania. Materials (pptx presentation) from Polish and Romanian seminar organised in October 2014 in the Institute of Agriculture at the Romanian Academy, Bucharest.

Boyadjieva P., Ilieva-Trichkova P. (2015). Institutional Diversity and Graduate Employability. In: R.M.O. Pritchard, M. Klumpp, U. Teichler (eds), Diversity and Excellence in Higher Education: Can the Challenges be Reconciled? (pp. 153-171). Rotterdam: SensePublishers.

Catrina S. (2015). Lines of division and threats of social cohesion - towards the question on the role of youth in transition processes and social changes. Materials (pptx presentation) from the international seminar organised within NCN project in May 2015 in Sopot.

Chan C.K.-C., Ngai P. (2009). The making of a new working class? A study of collective actions of migrant workers in South China. China quarterly, June, 198, 287-303; 
http://burawoy.berkeley.edu/Public\%20Sociology,\%20Live/Pun\%20Ngai/PunNgai. Protest.China\%20Quarterly.pdf [accessed: 14.08.2016].

China Youth Employment Report - Analysis Report of China's Survey on School to Work Transition. (2005). Youth Employment Network Office China Research Institute of Labor Sciences of Ministry of Labor and Social Security, International Labor Organization; http://www.ilo.org/beijing/what-we-do/publications/WCMS_158641/lang--en/index. htm [accessed:14.08.2016].

Chunling L. (2015). NEET phenomenon of youth after 80th and 90th in China. Journal of Chinese Youth Social Science, 4, p. 139 [in Chinese].

CIA database. The world fact book. https://www.cia.gov/library/publications/the-world-factbook/ [accessed: 14.08.2016].

Czarnowski S. (2006 [1935]). Ludzie zbędni w służbie przemocy. Miscellanea Anthropologica et Sociologica, 7, 95-101.

Elder S., Haas H., Principi M., Schewel K., International Labour Office. (2015). Youth and rural development: Evidence from 25 school-to-work transition surveys. Geneva: ILO; http://www.ilo.org/wcmsp5/groups/public/---dgreports/---dcomm/documents/publication/wcms_360558.pdf [accessed: 14.08.2016].

EUROSTAT database, http://ec.europa.eu/eurostat/data/database [accessed: 14.08.2016].

Hu Z., Peng X. (2015). Household changes in contemporary China: an analysis based on the four recent censuses. The Journal of Chinese Sociology, 2 (1), 1-20.

http://farmsubsidy.openspending.org [accessed: 14.08.2016].

International Labour Office. (2015). Global employment trends for youth 2015: Scaling up investments in decent jobs for youth. Geneva.

Ilieva-Trichkova P., Boyadjieva P. (2014). Dynamics of inequalities in access to higher education: Bulgaria in a comparative perspective. European Journal of Higher Education, 4 (2), 97-117.

ILOSTAT database, www.ilo.org/ilostat/faces/help_home/data_by_subject [accessed: 14.08.2016]

Knieć W. (2012). Wspólna Polityka Rolna a zrównoważony rozwój obszarów wiejskich Polski: Analiza socjologiczna. Toruń: Wydawnictwo Nukowe Uniwersytetu Mikołaja Kopernika.

Nowak L., Zakład Wydawnictw Statystycznych. (2013). Ludność Stan i struktura demograficzno-społeczna: Narodowy Spis Powszechny Ludności i Mieszkań 2011. Warszawa: Zakład Wydawnictw Statystycznych; http://stat.gov.pl/spisy-powszechne/nsp-2011/ nsp-2011-wyniki/ludnosc-stan-i-struktura-demograficzno-spoleczna-nsp-2011,16,1. html [accessed: 14.08.2016]

Mukhanova M.N. (2014). Rural youth in Russia: Their status and prospects for development. Eastern European Countryside, 1, 125-150.

Nguyen An Ha. (2015). Youth participation in the adulthood, materials gathered for the purposes of the seminar within the frameworks of project Młodziez w krajach postkomunistycznych. May 2015: Sopot.

Nurzyńska I. (2016). Polska wieś i rolnictwo jako beneficjenci funduszy Unii Europejskiej. In: J. Wilkin, I. Nurzyńska (eds), Polska wieś 2016. Raport o stanie wsi. Warszawa: FDPA. 
Survey assessment of Vietnamese youth 2: SAVY 2. 2010. Hanoi: General Office of Population and Family Planning.

Tang J. (2016). "Lost at the starting line": a reconsideration of educational inequality in China, 1978-2008. The Journal of Chinese Sociology, 3 (1), 8; https://doi.org/10.1186/ s40711-016-0028-z [accessed: 14.08.2016].

Tudor M.M. (2014). Romanian rural youth - socio-economic resilience factor. Materials (pptx presentation) from the international scientific conference: Młodzież w gospodarstwach rodzinnych i na obszarach wiejskich Europy, organised on 4-5 July 2014 by the University of Agriculture in Kraków.

Umbreș R., Sandu D., Stoica C.A. (2014). Romanian Youth: concerns, aspirations, attitudes and life style. Research report by the Center for Urban and Regional Sociology. CURS for Friedrich-Ebert-Stiftung Romania (FES); http://library.fes.de/pdf-files/bueros/ bukarest/12141.pdf [accessed: 14.08.2016].

UN HABITAT \& IESCO. (2015). China State of urban youth report 2014-2015. Equity employment and youth development in China. Overview and summary of findings; http:// unhabitat.org/china-state-of-urban-youth-report-2014-2015 [accessed: 14.08.2016].

United Nations. (2006). Guide to the implementation of the World Programme of Action for Youth: Recommendations and ideas for concrete action for policies and programmes that address the everyday realities and challenges of youth. New York.

United Nations. (2014). Demographic Yearbook 2014; http://unstats.un.org/unsd/demographic/products/dyb/dyb2.htm [accessed: 14.08.2016].

Wasielewski K. (2013). Młodzież wiejska na uniwersytecie - droga na studia, mechanizmy alokacji, postawy wobec kształcenia. Toruń: Wydawnictwo Naukowe UMK.

Wilkin J. (2010). Czy paradygmat wielofunkcyjnego rolnictwa zrewolucjonizuje europejska politykę rolną? Podsumowanie badań i wnioski praktyczne. In: J. Wilkin (ed.), Wielofunkcyjność rolnictwa. Kierunki badań, podstawy metodologiczne i implikacje praktyczne. Warszawa: Instytut Rozwoju Wsi i Rolnictwa Polskiej Akademii Nauk.

Wilkin J., Nurzyńska I. (eds) (2016). Polska wieś 2016. Raport o stanie wsi. Warszawa: FDPA. Xi J., Xia Y. (2006). Introduction to Chinese Youth (with a Commentary). DigitalCommons@ University of Nebraska - Lincoln; http://digitalcommons.unl.edu/cgi/viewcontent. cgi? article $=1001 \&$ context $=$ cyfsfacpub [accessed: 14.08 .2016 ]

Zhang J. (2004). China's Skill Assessment System. Institute of Population and Labor Economics Chinese Academy of Social Sciences; http://siteresources.worldbank.org/ EDUCATION/Resources/278200-1126210664195/1636971-1126210694253/China_ Skills_Assessment.pdf [accessed: 14.08.2016]. 


\section{Przejście od edukacji do zatrudnienia - specyfika wiejskiej młodzieży wybranych krajów postkomunistycznych}

Streszczenie: Przedmiotem analiz jest proces wchodzenia na rynek pracy, rozpatrywany w odniesieniu do młodzieży wiejskiej wybranych postkomunistycznych krajów (Polski, Rumunii, Rosji, Chin i Wietnamu). Podstawą źródłową są różnego typu dane zastane (monografie naukowe, raporty krajowe i międzynarodowe, statystyki urzędowe) gromadzone w projekcie międzynarodowym finansowanym przez Narodowe Centrum Nauki w Polsce. Przejście od edukacji do satysfakcjonującego zatrudnienia, które współcześnie zajmuje ludziom młodym niemal całą trzecią dekadę życia, jest tylko zewnętrznym przejawem zmian, jakie zachodzą na rynkach pracy w całym świecie. Polska reprezentuje w analizowanej grupie krajów jedyny przypadek, gdzie zarówno korzystanie z nowych ofert edukacyjnych, jak i pozytywne wartościowanie życia na wsi pojawia się w skali niespotykanej w innych krajach, niemniej i tutaj szans życiowych młodzi ludzie upatrują w miastach, gdzie stają do trudnej rywalizacji o zatrudnienie. Młodzież wiejska we wszystkich analizowanych krajach zazwyczaj reprezentuje typ karier chaotycznych, sytuujących ją w segmentach pracy nieformalnej, tymczasowej lub samozatrudnienia.

Słowa kluczowe: rynek pracy, młodzież wiejska, kraje postkomunistyczne. 
